\title{
Shoot Density Affects 'Riesling' Grapevines II. Wine Composition and Sensory Response
}

\author{
A.G. Reynolds, ${ }^{1}$ C.G. Edwards, ${ }^{2}$ D.A. Wardle, ${ }^{3}$ D. Webster, ${ }^{4}$ and M. Dever ${ }^{5}$ \\ Agriculture Canada Research Station, Summerland, B.C. VOH 1Z0, Canada \\ Additional index words. Vitis vinifera, cluster thinning, pruning, canopy management, monoterpenes
}

\begin{abstract}
Riesling' grapevines (Vitis vinifera L.) were subjected for 4 seasons (1987-90) to three shoot densities (16, 26, and 36 shoots $/ m$ of row) combined with three crop-thinning levels $(1,1.5$, and 2 clusters per shoot $)$ in a factorial design. Wines were made from all treatment combinations in 1989. Aroma compounds such as trans-3-hexen-1-ol, linalool, and linalool oxides 1 and 2 in many cases decreased in nonaged and aged wines by increasing shoot density and clusters per shoot, while cis-3-hexen-1-ol increased. Aging wines increased concentrations of cis-3-hexen-1-ol, citronellol, $\alpha$-terpineol, and the linalool oxides, while linalool decreased. Tasters identified aged wines from the lowest shoot densities and clusters per shoot as having the most ripe-fruit flavor and the least green-fruit flavor and perceived acidity. Flavor descriptors were correlated with linalool, cis-3-hexen-1-ol, and linalool oxide 1 . Shoot densities of 20 to 25 shoots $/ \mathrm{m}$ of row are recommended for low to moderately vigorous 'Riesling' vines to achieve economically acceptable yields and high wine quality simultaneously.
\end{abstract}

The number of nodes retained on a grapevine depends to some degree on vine vigor, spacing, and training system, with recommendations usually given in terms of pruning level or shoot density. Several reports have provided pruning level guidelines with the objective of balancing vine vigor, yield, and fruit quality. Among these are recommendations for Vitis labruscana Bailey (Partridge, 1925; Shaulis and Oberle, 1948; Shaulis and Robinson, 1953; Tomkins and Shaulis, 1955) and French-American hybrids (Morris et al., 1984; Reynolds et al., 1986). Few reports have investigated optimizing shoot density levels for Vitis vinifera (Basler 1980, 1981; Kiefer and Crusius, 1984; Murisier and Ziegler, 1991; Nikov, 1987; Smart, 1988). Reynolds (1988) found that 25 shoots/m (of row) was equivalent to $30+10$ balanced pruning of moderately vigorous 'Riesling' vines in terms of vine size, yield, and fruit composition. Recommendations for Vitis vinifera in British Columbia are based partly on these data.

Based on an interpolation of several research reports (Basler 1980, 1981; Kiefer and Crusius, 1984; Murisier and Ziegler, 1991; Nikov, 1987; Smart, 1988), shoot densities between 15 and 25 shoots/m may lead to improved canopy microclimate, with high bud fruitfulness, optimum bud hardiness, higher soluble solids, lower titratable acidity and $\mathrm{pH}$, enhanced varietal character, minimized vegetative flavors, and improved color than shoot densities $>25$ shoots $/ \mathrm{m}$. Furthermore, recent research has investigated the relationship between viticultural practices such as shoot density and crop-thinning level on aroma compounds in grapes and wines. Monoterpenes increased in response to crop-thinning level reductions in 'Riesling' (McCarthy, 1986) and 'Müller-Thurgau' (Eschenbruch et al., 1987). High N fertilization reduced monoterpenes in 'Riesling' wines (Webster et al., 1993). Basal leaf

Received for publication 27 Sept. 1993. Accepted for publication 17 Jan. 1994. This research was conducted at the Agriculture Canada Research Station and Washington State Univ., Pullman. We gratefully acknowledge the cooperation and interest of Daniel Dulik, Pioneer Vineyards, Kelowna, B.C. We also thank Jean Hogue for technical assistance in the field, 1987-90. The cost of publishing this paper was defrayed in part by the payment of page charges. Under postal regulations, this paper therefore must be hereby marked advertisement solely to indicate this fact. ${ }^{1}$ Research scientist, Pomology and Viticulture Section.

${ }^{2}$ Assistant professor, Dept. of Food Science, Washington State Univ., Pullman, WA 99164.

${ }^{3}$ Research scientist, Pomology and Viticulture Section.

${ }^{4}$ Research assistant, Dept. of Food Science, Washington State Univ., Pullman, WA 99164.

${ }^{5}$ Research assistant, Food Processing Section. removal increased monoterpenes in 'Gewürztraminer' (Reynolds and Wardle, 1989a), 'Riesling' (Reynolds et al., 1991), and 'Sauvignon blanc' (Smith et al., 1988). However, demonstrating a relationship between sensory data and monoterpene concentration has been less successful. With regard to wine aging, transformations of monoterpenes such as decreases in linalool and corresponding increases in linalool oxides have been reported (DiStefano and Castino, 1983; Nicolosi-Asmundo et al., 1988; Rapp, 1990).

Currently, shoot density guidelines for $V$. vinifera under North American environmental conditions are not available. Furthermore, research addressing interactions between shoot density and crop-thinning level has not been published. The objectives of the first part of this study (Reynolds et al., 1994) was to assess the effects of moderate to high shoot densities and their interactions with crop-thinning level in terms of vine performance, canopy microclimate, and fruit composition of 'Riesling' grapes. The objectives of this portion of the study were to examine some of the major aroma constituents in the wines relative to the vineyard treatments, observe possible changes in these compounds during wine aging, and relate the levels of these constituents to wine aroma and flavor descriptors.

\section{Materials and Methods}

Experimental design and plant material: winemaking procedures. Detailed aspects of the experimental design can be found in Reynolds et al. (1994). The experimental design was a randomized complete block with four blocks and five vine treatment replicates. Three shoot densities $(16,26$, and 36 shoots/m) were combined in a factorial treatment arrangement with three crop-thinning levels ( $1,1.5$, and 2 clusters/shoot) to provide nine treatment combinations. Treatment combinations indicating a specific shoot density and crop-thinning level will be designated as shoot density/cropthinning level numbers (16/1, 26/1.5, 36/2, etc.). Analysis of all data was performed by the SAS statistical package (SAS Institute, Cary, N.C.) using the PROC GLM and PROC CORR procedures.

About $15 \mathrm{~kg}$ of fruit per treatment replicate was retained at harvest in 1989 (16 Oct.) for winemaking. Grapes were stored at 2C for $24 \mathrm{~h}$, crushed in a crusher-destemmer, allowed 48-h skin contact without sulfite at $2 \mathrm{C}$, and pressed in a hydraulic rack-andcloth press. Musts from the individual treatment replicates from blocks 1 and 2 and those from blocks 3 and 4, were blended, respectively, into 20-liter glass carboys to give two fermentation 
replicates for each treatment combination. Musts were sulfited to $50 \mathrm{mg} \cdot \mathrm{liter}^{-1}$ free $\mathrm{SO}_{2}$, settled for $24 \mathrm{~h}$ at $2 \mathrm{C}$, racked, and placed into a fermentation room maintained at $15 \mathrm{C}$. After $24 \mathrm{~h}$, a yeast inoculum (Saccharomyces cereviseae Hansen, strain Montrachet; Red Star Co., Milwaukee), grown for 3 days in 'Riesling' juice was added to each carboy at a rate of $3 \%(\mathrm{v} / \mathrm{v})$. Fermentation proceeded until wines reached $\approx 1.5 \%$ residual sugar (confirmed by Clinitest tablets), at which point they were sulfited to $50 \mathrm{mg} \cdot \mathrm{liter}^{-1}$ free $\mathrm{SO}_{2}$, racked, cold-stabilized at $-2 \mathrm{C}$ for $\approx 30$ days, racked again, and stored at 2C until bottling in March 1990.

Wine composition. Wine $\mathrm{pH}$ was measured as described previously for berries (Reynolds et al., 1994). Wine TA was measured on 10-ml samples using a titroprocessor (Brinkmann 672; Metrohm, Herisau, Switzerland) according to Amerine and Ough (1980). Ethanol was measured on the wines using a gas chromatograph (model 5700; Hewlett-Packard, Mississauga, Ont.).

Wine aroma volatiles. Two $250-\mathrm{ml}$ samples of wine per treatment $\times$ fermentation replicate were taken at time of bottling (nonaged) and 11 months thereafter (aged) and stored at-40C until analysis. Extraction and quantitation of aroma volatiles were performed as described by Webster et al. (1993). Two six-carbon alcohols (trans-3-hexen-1-ol, and cis-3-hexen-1-ol) and five free monoterpenes (citronellol, linalool, $\alpha$-terpineol, linalool oxide 1, and linalool oxide 2) were identified by gas chromatography-mass spectroscopy (Webster et al., 1993).
Sensory evaluation. Wines were tasted in February 1991 after 11 months of bottle storage. Three aroma descriptors (ripe fruit, green fruit, and corky-musty) and four flavor descriptors (ripe fruit, green fruit, sweetness, and acidity) were developed through consensus by a trained 12-member taste panel. Intensity of each aroma and flavor descriptor was assessed on a 100-point line scoresheet. The two fermentation replicates were assessed at two

Table 1.Composition of 'Riesling' wines (1989) in response to three shoot densities and three crop-thinning levels.

\begin{tabular}{|c|c|c|c|}
\hline \multirow[b]{2}{*}{ Factor } & \multicolumn{3}{|c|}{ Wine } \\
\hline & TA $\left(\mathrm{g} \cdot\right.$ liter $\left.^{-1}\right)$ & $\mathrm{pH}$ & Ethanol (\%) \\
\hline \multicolumn{4}{|c|}{ Shoot density (shoots/m row) } \\
\hline 16 & 8.7 & 3.08 & 14.75 \\
\hline 26 & 9.3 & 3.03 & 14.59 \\
\hline 36 & 9.0 & 3.06 & 15.86 \\
\hline Significance & $\mathrm{Q}^{*}$ & $\mathrm{Q}^{*}$ & $\mathrm{~L}^{* * * *}, \mathrm{Q}$ \\
\hline \multicolumn{4}{|c|}{ Crop thinning level (cluster/shoot) } \\
\hline 1 & 8.8 & 3.08 & 14.85 \\
\hline 1.5 & 9.0 & 3.06 & 14.86 \\
\hline 2 & 9.2 & 3.03 & 15.55 \\
\hline Significance & NS & NS & $\mathrm{L}^{* * * *}, \mathrm{Q}^{* *}$ \\
\hline
\end{tabular}

$\widehat{\mathrm{Ns}, *, * *, * * *}$ Nonsignificant or significant at $P \leq 0.05,0.01$, or 0.001 , respectively. $\mathrm{L}=$ linear, $\mathrm{Q}=$ quadratic.

\section{VOLATILE COMPOUNDS IN NON-AGED RIESLING WINES}

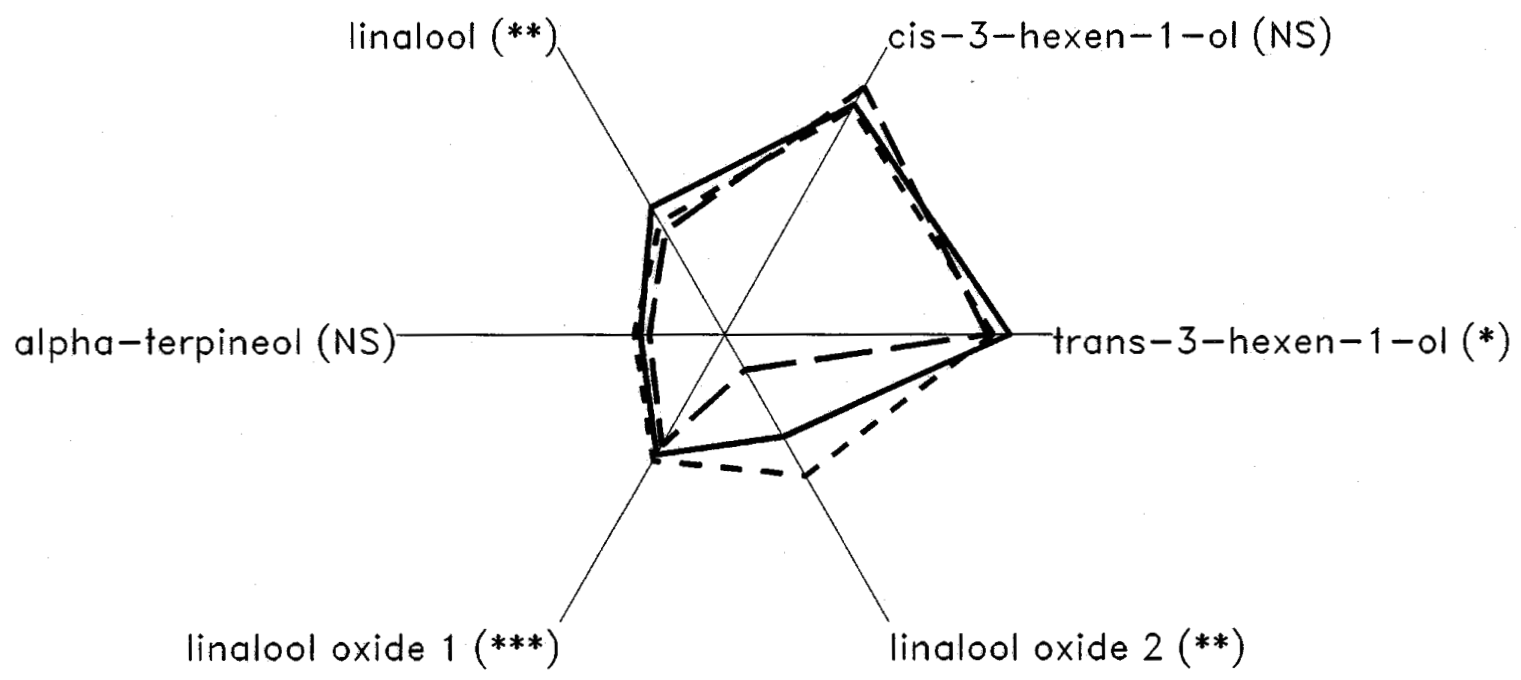

Fig. 1. Concentration of some volatile compounds $\left(\mu \mathrm{g} \cdot \mathrm{liter}^{-1}\right)$ of nonaged 'Riesling' wines in response to three shoot densities, 1989. ${ }^{\mathrm{Ns}, * * *, * * * *}$ Nonsignificant or significant at $P<0.05,0.01$, or 0.001 , respectively. Linear or quadratic trends were not estimable. Axis length $=80 \mu \mathrm{g}$. 
separate tastings. All treatments were presented as $30-\mathrm{ml}$ samples in clear tulip-shaped glasses and were randomized for each taster. Results were analyzed by analysis of variance and by principal components analysis (PCA).

\section{Results}

Wine composition. Wines in 1989 tended to show the same trends displayed by the berry samples in 1987-90 and the juice samples in 1989. Wine TA displayed a slight quadratic increase relative to increasing shoot density (Table 1), a trend supported by a significant correlation $(P \leq 0.008)$ between shoots per vine and wine TA. Wine $\mathrm{pH}$ was lowest at 26 shoots/m (Table 1). Ethanol increased relative to increasing shoot density and clusters per shoot
(Table 1), a trend supported by significant correlations $(P \leq$ 0.0001 ) between ethanol and shoots per vine and clusters per vine. Crop-thinning level had no significant effect on wine TA or $\mathrm{pH}$, and there were no interactions between the two factors for these variables. Significant correlations $(P \leq 0.01)$ occurred, however, between clusters per vine and wine TA (positive) and wine $\mathrm{pH}$ (negative). A significant shoot density $\times$ crop-thinning interaction (data not shown) indicated that ethanol did not increase with clusters per shoot at the highest shoot density.

Wine aroma volatiles. Trends in aroma volatile concentration relative to shoot density and crop-thinning level were similar for nonaged and aged wines. Concentrations of trans-3-hexen-1-ol, linalool, and linalool oxides 1 and 2 in nonaged wines decreased with increasing shoot density (Fig. 1). In aged wines, linalool and linalool

\section{VOLATILE COMPOUNDS IN AGED RIESLING WINES}

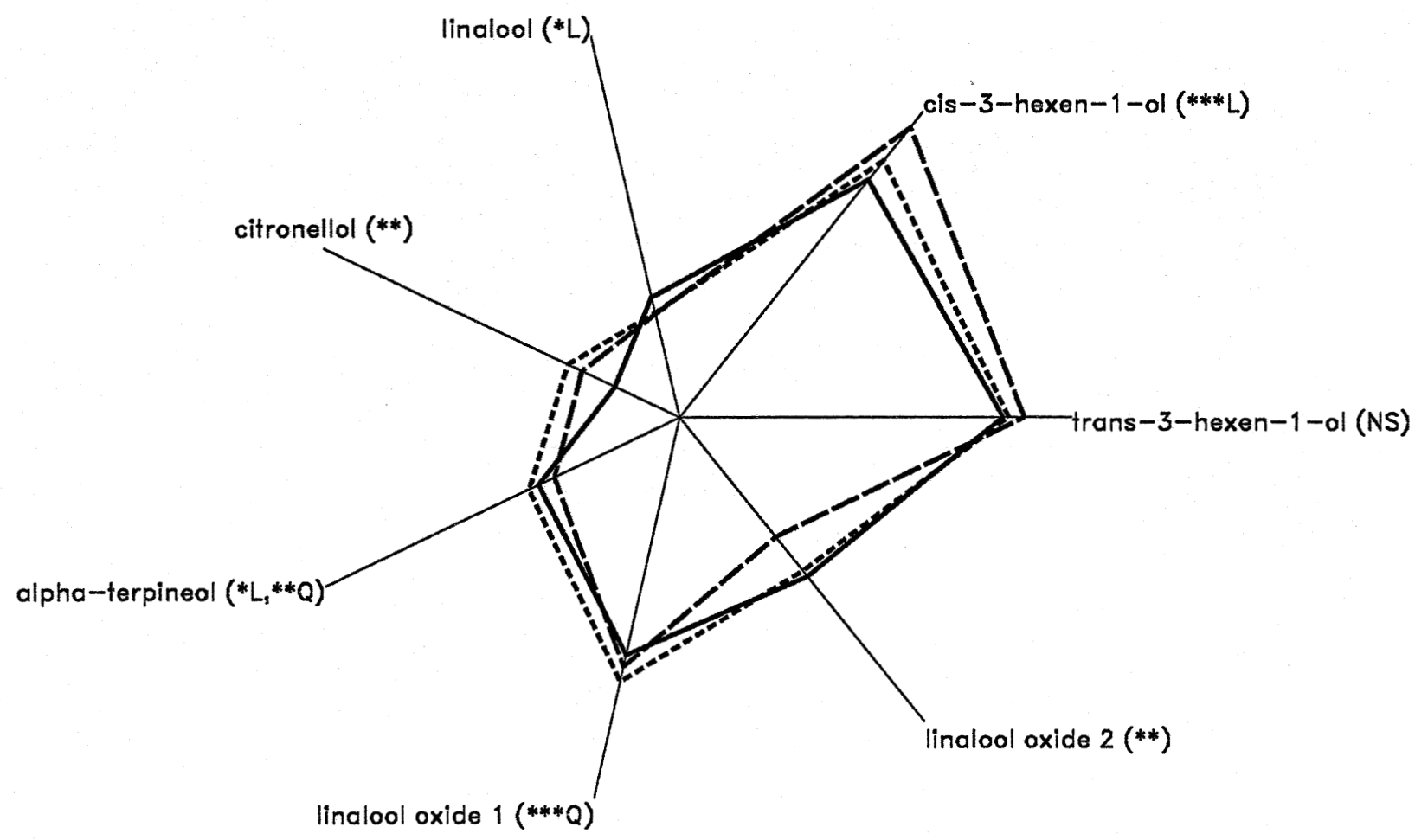


oxide 2 displayed the same trend, but trans-3-hexen-1-ol and linalool oxide 1 displayed quadratic responses to shoot density. Cis-3-hexen1-ol and citronellol also increased linearly with increasing shoot density in aged wines, while $\alpha$-terpineol decreased (Fig. 2).

Increasing clusters per shoot decreased trans-3-hexen-1-ol in nonaged wines (Fig. 3) and citronellol and linalool in aged wines (Fig. 4). Cis-3-hexen-1-ol and linalool oxide 1 in nonaged and aged wines increased relative to increasing clusters per shoot. $\alpha$ Terpineol in nonaged wines and trans-3-hexen-1-ol, $\alpha$-terpineol, and linalool oxide 2 in aged wines showed quadratic trends in response to crop-thinning level, with lowest concentrations detected at 1.5 clusters/shoot.

Shoot density $\times$ crop-thinning interactions occurred for transand cis-3-hexen-1-ol, $\alpha$-terpineol, and linalool oxide 1 in nonaged wines (Fig. 5) and for all but cis-3-hexen-1-ol and linalool in aged wines (Fig. 6). Trends in the concentrations of these compounds varied greatly in their magnitude and direction of response to the two factors, and no simple, consistent pattern of response was apparent. However, lowest concentrations of all aroma compounds always occurred in treatment combinations consisting of moderate to high clusters per shoot ( 1.5 or 2 clusters/shoot) and/or shoot densities of 36 shoots $/ \mathrm{m}$. Furthermore, when concentrations of these aroma compounds were examined within treatment groups containing equal cluster numbers but different shoot densities, the two hexenols increased relative to increasing shoot density, while the monoterpenes tended to decrease.

Cis-3-hexen-1-ol and all monoterpenes except linalool increased in concentration after 11 months of bottle storage (Table 2 ). There were significant interactions for age $\times$ shoot density (cis3-hexen-1-ol, citronellol, and linalool oxide 2 ), age $\times$ crop thinning (cis-3-hexen-1-ol and linalool oxide 1 ), and age $\times$ shoot density $\times$ crop thinning (linalool oxide 1). Age $\times$ shoot density and age $\times$ crop-thinning interactions suggested that the magnitude of response of each aroma compound to age increased with increasing shoot density or clusters per shoot (data not shown). The three-way interaction for linalool oxide 1 indicated that increases in this compound in response to bottle age were least apparent at the 16/ 1 treatment combination. Highest concentrations $\left(66 \mu \mathrm{g} \cdot \mathrm{liter}^{-1}\right)$ were found in aged wines of the $26 / 2$ combination, while lowest concentrations $\left(25 \mu \mathrm{g} \cdot \mathrm{liter}^{-1}\right)$ were found in the nonaged wines of the $16 / 1.5$ and $26 / 1.5$ combinations.

Sensory evaluation. Tasters found no effect of shoot density on any of the aroma descriptors (Fig. 7), but perceived a reduction in ripe-fruit character relative to increased clusters per shoot (Fig. 8). Linear reductions in ripe-fruit flavor and sweetness and increases in green-fruit flavor and perceived acidity were associated with increased shoot density and clusters per shoot (Figs. 7 and 8).

Interactions showed that tasters found the highest levels of negative flavor descriptors (green fruit and acidity) and the lowest ripe-fruit flavor in the 36 shoots/m treatments and in the 26/2

\section{VOLATILE COMPOUNDS IN NON-AGED RIESLING WINES}

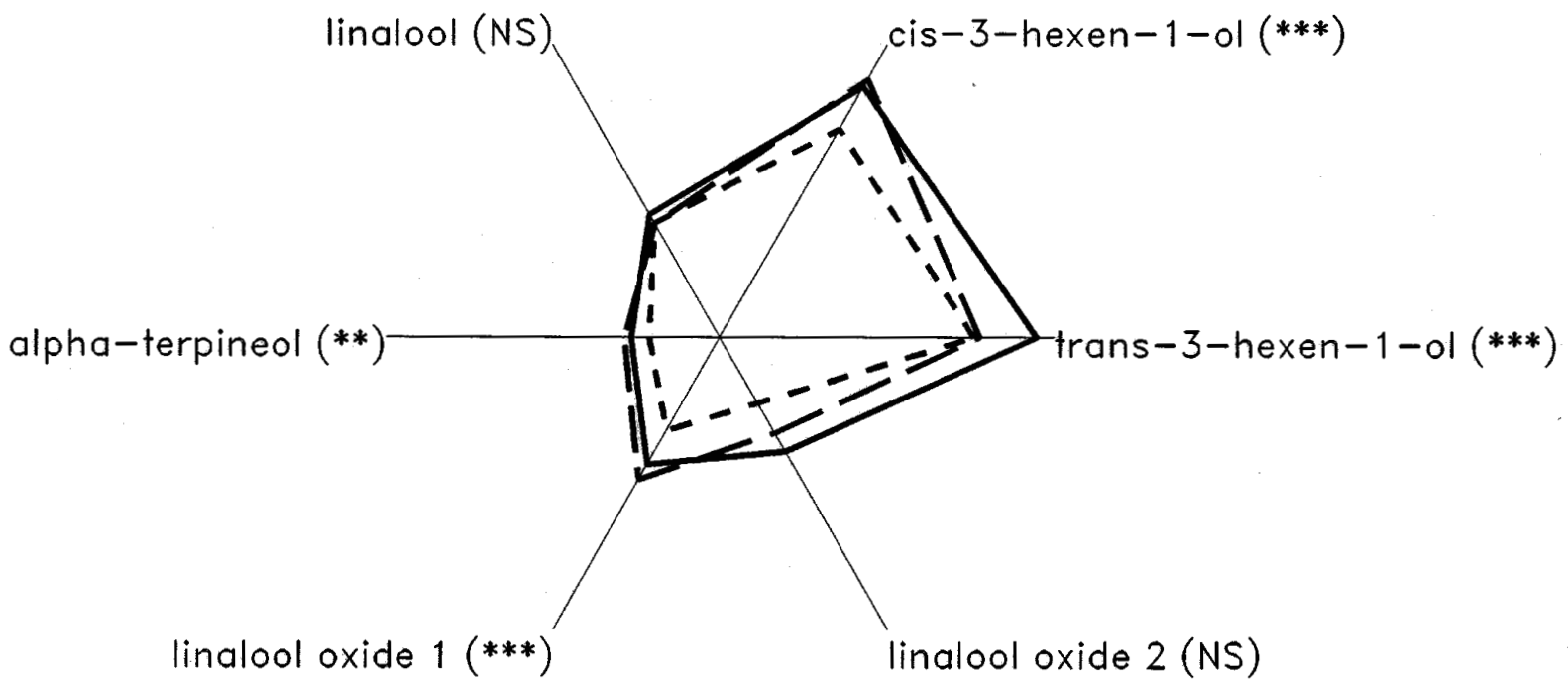

Fig. 3. Concentration of some volatile compounds $\left(\mu \mathrm{g} \cdot \mathrm{liter}^{-1}\right)$ of nonaged 'Riesling' wines in response to three crop-thinning levels, 1989. ns, ,***,****Nonsignificant or significant at $P<0.05,0.01$, or 0.001 respectively. Linear or quadratic trends were not estimable. Axis length $=80 \mu \mathrm{g}$. 


\section{VOLATILE COMPOUNDS IN AGED RIESLING WINES}
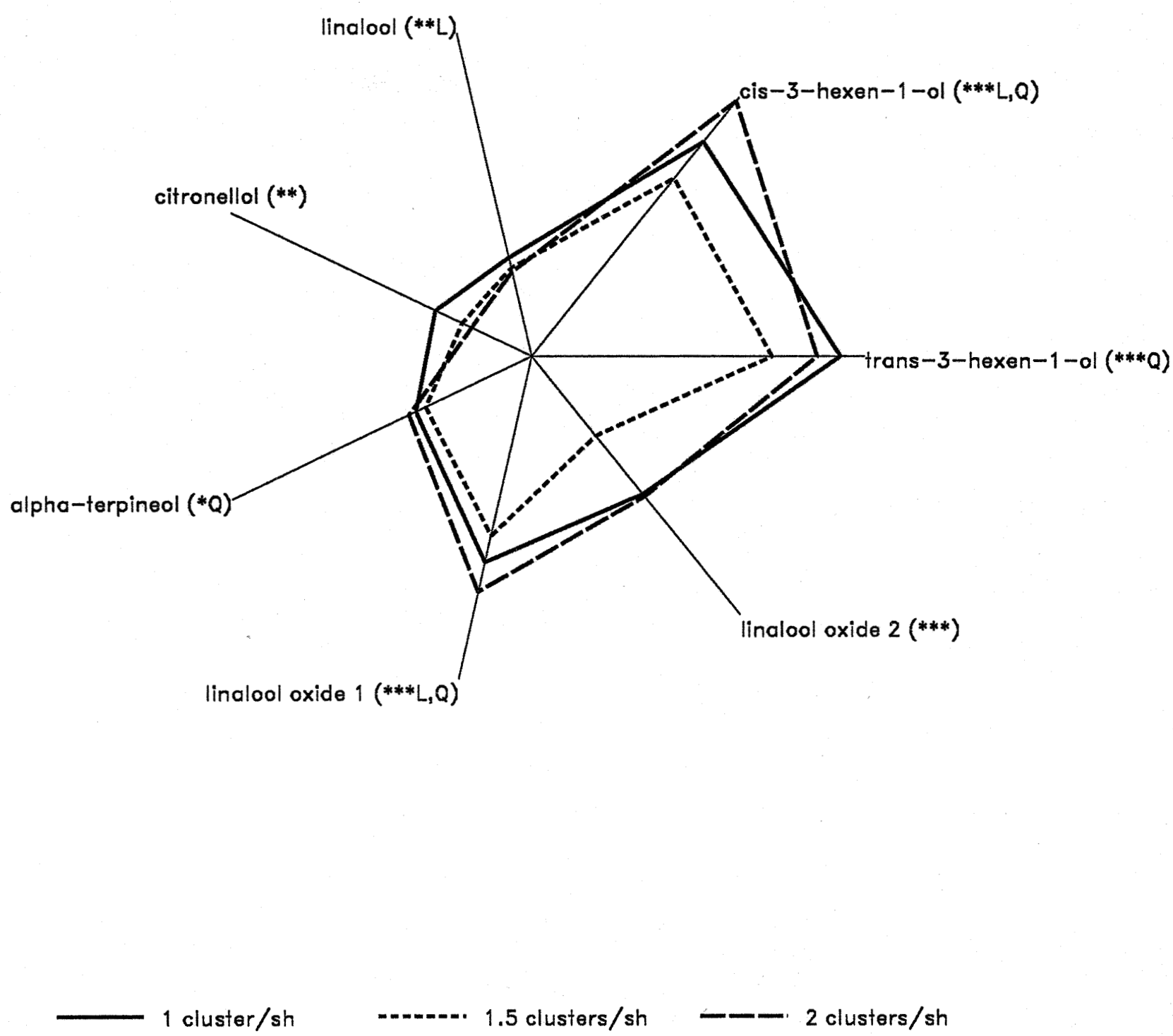

Fig. 4. Concentration of some volatile compounds $\left(\mu \mathrm{g} \cdot \mathrm{liter}^{-1}\right)$ of aged 'Riesling' wines in response to three crop-thinning levels, 1989. ${ }^{\text {ss, }, * * * * * *}$ Nonsignificant or significant at $P<0.05,0.01$, or 0.001 respectively; $\mathrm{L}=$ linear, $\mathrm{Q}=$ quadratic. Axis length $=82 \mu \mathrm{g}$.

treatment combination (data not shown). Highest level of ripe-fruit flavor and lowest level of green-fruit flavor were found in the 16/ 1 treatment. Increased clusters per shoot decreased ripe-fruit flavor linearly at 16 shoots/m but had no impact at 36 shoots $/ \mathrm{m}$. Greenfruit flavor also was unaffected by crop-thinning level at the highest shoot density. Perceived sweetness and acidity followed the same patterns as ripe fruit and green fruit, respectively. These patterns were clearly shown by PCA (Fig. 9), which separated the 36 shoots/m treatments and the 26/2 treatment from the other combinations. Comparisons between treatments within treatment groups A (16/1.5 and 26/1) and C (26/2 and 36/1.5) showed no apparent effect of shoot density at equal cluster number, but, within treatment group B $(16 / 2,26 / 1.5$, and $36 / 1)$, the $26 / 1.5$ combination seemed to be favored in terms of highest ripe-fruit flavor and perceived sweetness and lowest green-fruit flavor and perceived acidity. Most shoot density effects implied by the main effects were present at each crop-thinning level among the interactions.

Correlations existed between the seven sensory descriptors, between the aroma compounds, and between the flavor descriptors and concentration of aroma compounds in the aged wines (Table $3)$. Ripe-fruit aroma was positively correlated with sweetness and negatively correlated with musty aroma. Ripe-fruit flavor and 

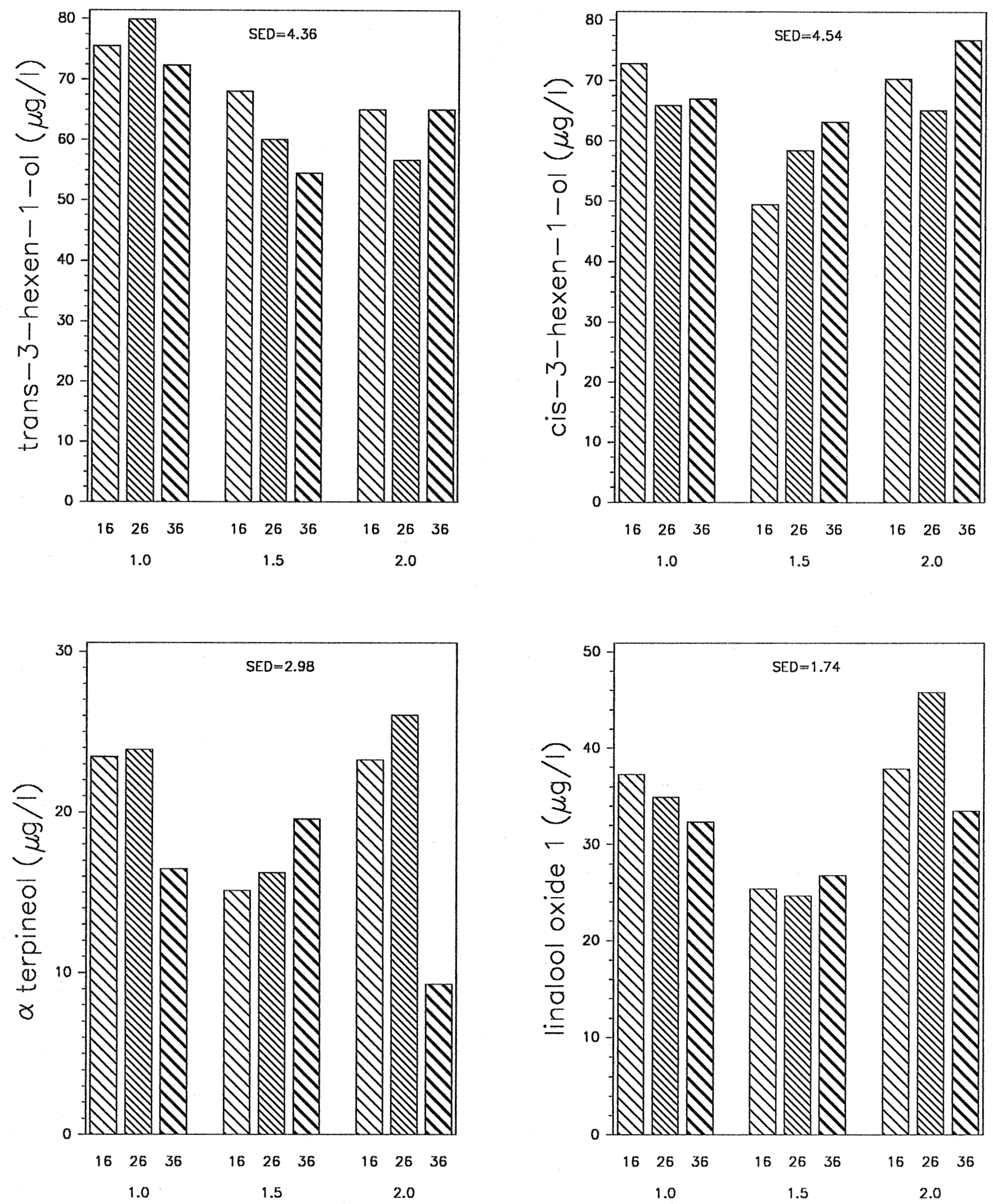

Fig. 5. Shoot density $\times$ crop-thinning level interactions and significance levels for nonaged 'Riesling' wines, 1989. Trans-2-hexen-1-ol, cis-3-hexen-1-ol, and $\alpha$-terpineol significant at $P<0.05$; linalool oxide 1 significant at $P<0.01$.

sweetness were positively correlated, and these descriptors were negatively correlated with green-fruit flavor. Descriptors of similar aroma and flavor characteristics (e.g., ripe-fruit aroma vs. ripefruit flavor) were highly correlated. Many of the monoterpenes were positively correlated with each other and negatively correlated with the hexenols. Cis-3-hexen-1-ol and linalool oxide 1 were positively correlated with green-fruit flavor and negatively correlated with ripe-fruit flavor and sweetness. Linalool was 

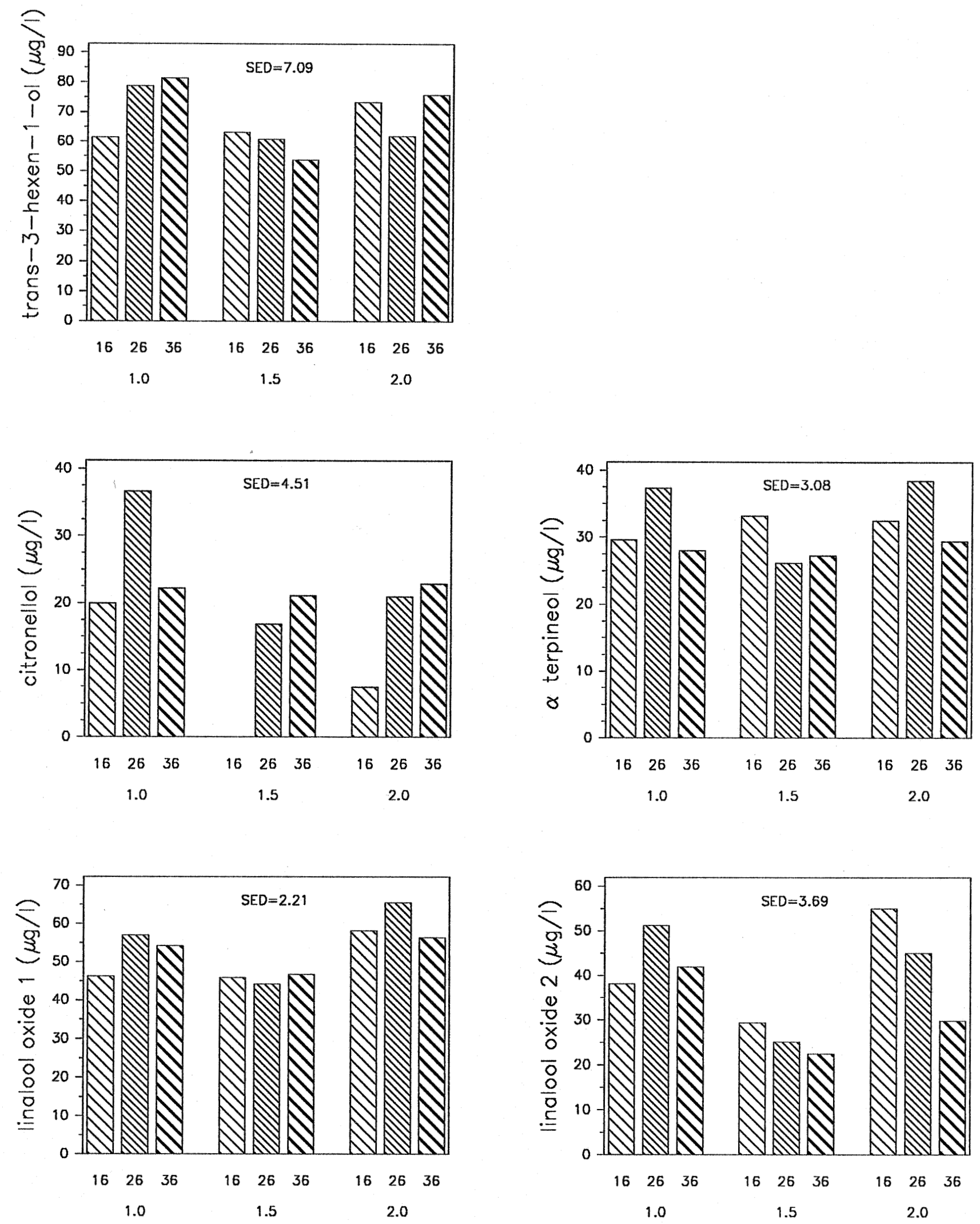

Fig. 6. Shoot density $\times$ crop-thinning level interactions and significance levels for aged 'Riesling' wines, 1989. Trans-2-hexen-1-ol and citronellol significant at $P<0.05$; $\alpha$-terpineol significant at $P<0.01$; linalool oxide 1 significant at $P<0.001$; linalool oxide 2 significant at $P<0.01$.

positively correlated with ripe-fruit flavor and sweetness and negatively correlated with green-fruit flavor. Citronellol was negatively correlated with sweetness, while linalool oxide 2 was negatively correlated with green-fruit flavor.

\section{Discussion}

Increasing nodes retained per vine (shoot density) leads to more clusters per vine, hence higher yield, but also increases canopy 
Table 2. Concentration of some volatile compounds $\left(\mu \mathrm{g} \cdot\right.$ liter $\left.^{-1}\right)$ of 'Riesling' wines in response to wine age. Means are pooled across nine vineyard treatments imposed in 1989.

\begin{tabular}{|c|c|c|c|c|c|c|}
\hline \multirow[b]{3}{*}{ Compound } & \multicolumn{2}{|c|}{ Wine age } & & & & \\
\hline & \multirow[b]{2}{*}{ Bottling } & \multirow{2}{*}{$\begin{array}{c}11 \text { Months } \\
\text { postbottling }\end{array}$} & \multicolumn{4}{|c|}{ Significance $^{\mathrm{z}}$} \\
\hline & & & A & $\mathrm{A} \times \mathrm{SD}$ & $\mathrm{A} \times \mathrm{CL}$ & $\mathrm{A} \times \mathrm{SD} \times \mathrm{CL}$ \\
\hline Trans-3-hexen-1-ol & 66.37 & 67.81 & NS & NS & NS & NS \\
\hline Cis-3-hexen-1-ol & 65.45 & 68.59 & $*$ & $*$ & $*$ & NS \\
\hline Linalool & 32.02 & 23.02 & $* * *$ & NS & NS & NS \\
\hline Citronellol & 17.74 & 21.40 & $*$ & $* * *$ & NS & NS \\
\hline$\alpha$-Terpineol & 20.37 & 31.33 & $* * *$ & NS & $* *$ & NS \\
\hline Linalool oxide 1 & 33.15 & 52.72 & $* * *$ & $* *$ & NS & $* *$ \\
\hline Linalool oxide 2 & 27.46 & 38.01 & $* * *$ & NS & $* *$ & NS \\
\hline
\end{tabular}

${ }^{\mathrm{z}} \mathrm{A}=$ age; $\mathrm{SD}=$ shoot density; $\mathrm{CL}=$ crop-thinning level.

Ns, ${ }^{* * *, * * *}$ Nonsignificant or significant at $P \leq 0.05,0.01$, or 0.001 , respectively.

\section{SENSORY ATTRIBUTES OF AGED RIESLING WINES}

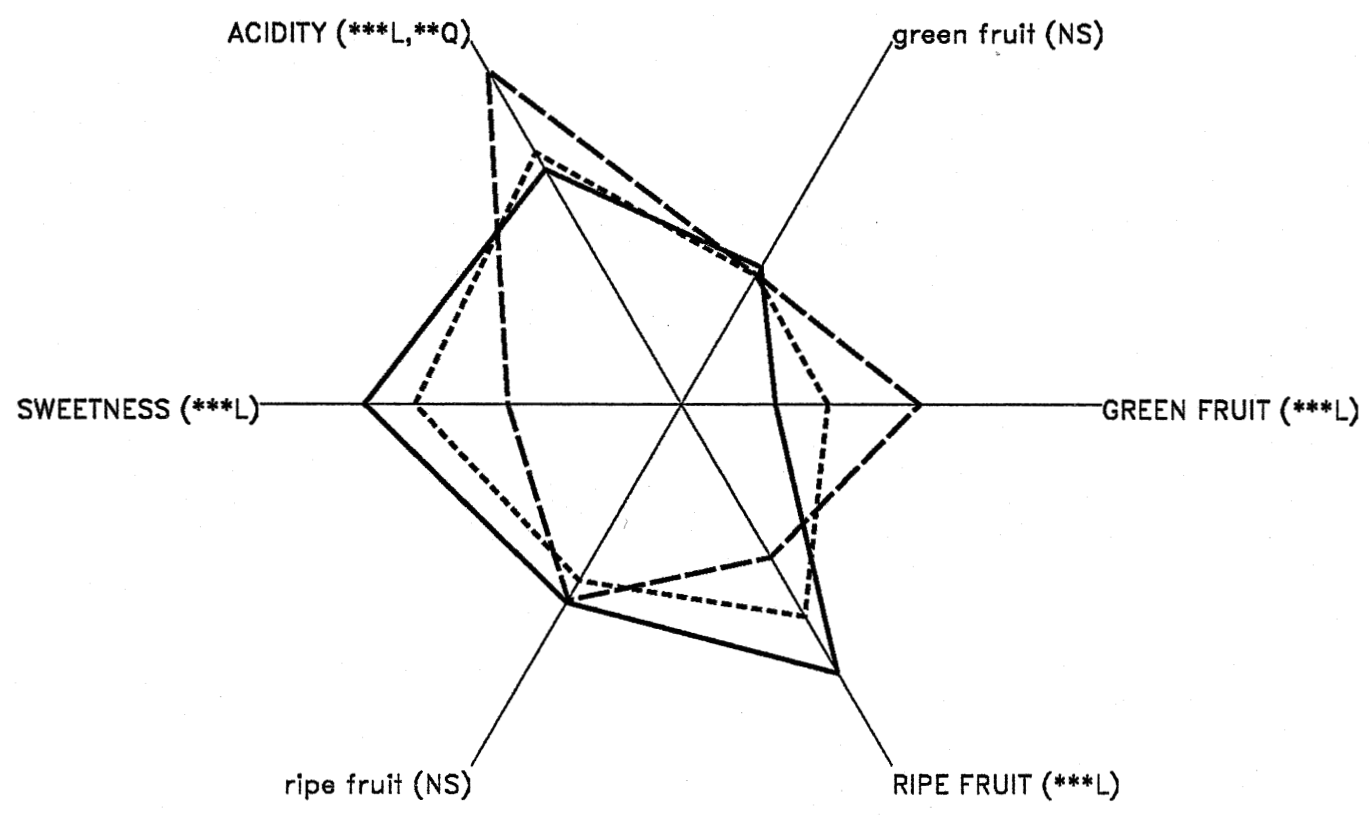




\section{SENSORY ATTRIBUTES OF AGED RIESLING WINES}

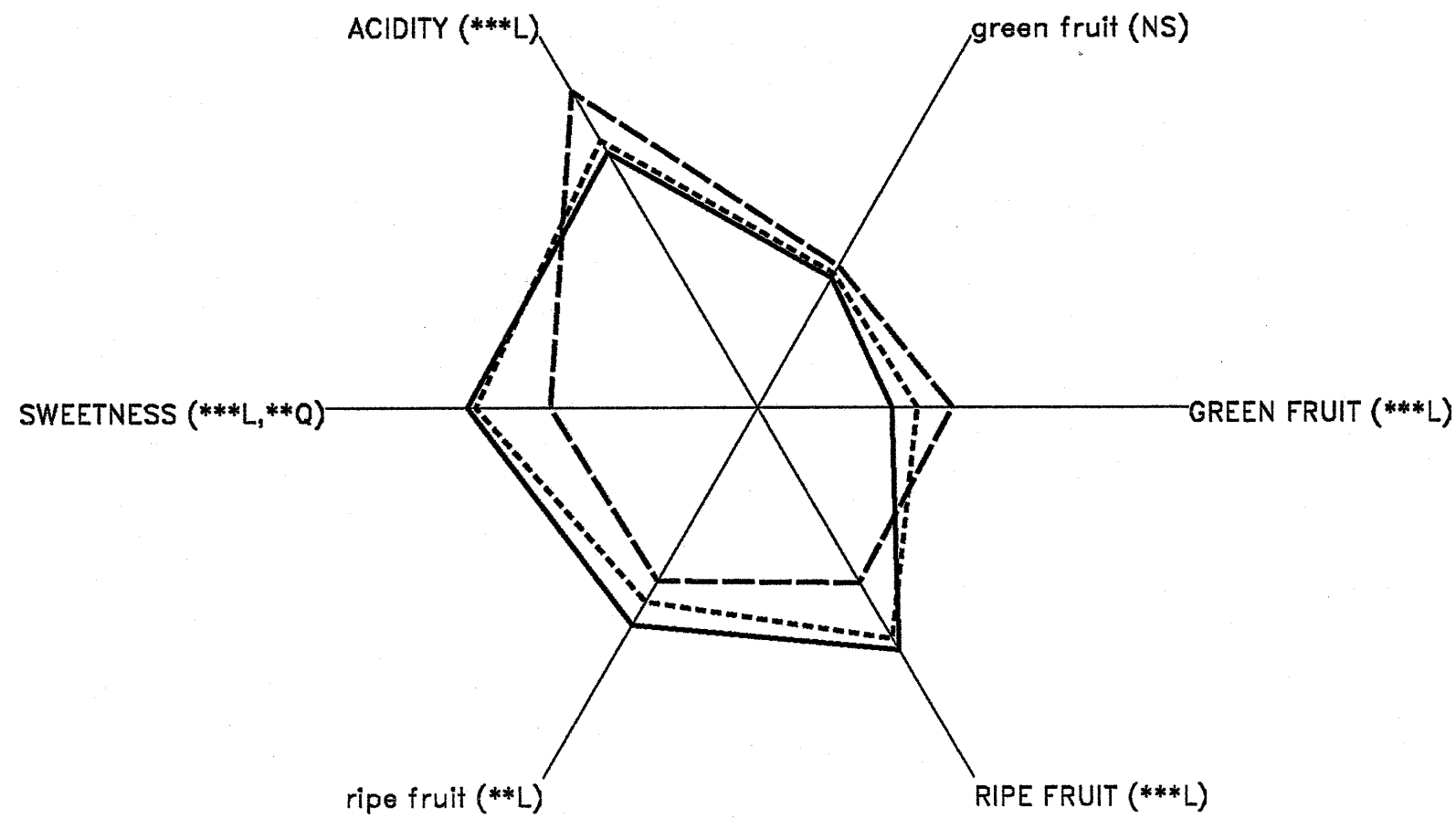

- 1 CLUSTER/SH $\quad \cdots \cdots+2$ CLUSTERS/SH

Fig. 8. Mean intensity plot of aroma (lowercase) and flavor (uppercase) descriptors for 'Riesling' wines in response to three crop-thinning levels, 1989. Ns,*******Nonsignificant or significant at $P<0.01$ or 0.001 , respectively; $\mathrm{L}=$ linear, $\mathrm{Q}=$ quadratic. Axis length $=60$ points.

density (Shaulis, 1982: Shaulis and May, 1971; Smart, 1988). Results of these phenomena are higher crop loads (yield : vine size ratio), increased canopy shade, and reduced light interception in the canopy interior (Shaulis, 1982). Reductions in clusters per shoot by cluster thinning or as a result of shade-induced decline in fruitfulness may partly mitigate the debilitating effects of high crop load on yield components. Lowering clusters per shoot by cluster thinning may increase cluster weight, berries per cluster, and berry weight and may also significantly advance fruit maturity (Fisher et al., 1977; Reynolds, 1989; Reynolds et al., 1986).
The shoot densities imposed in this experiment ranged from 16 to 36 shoots $/ \mathrm{m}$ of row. Sixteen shoots $/ \mathrm{m}$ of row $\left(6.8\right.$ shoots $/ \mathrm{m}^{2}$ in this trial) is a level considered about optimal by some (Kiefer and Crusius, 1984; Reynolds et al., 1986; Smart, 1988), high by others (Basler, 1980, 1981; Murisier and Ziegler, 1991), but low by grower standards (J. Vielvoye, personal communication). Twentysix shoots $/ \mathrm{m}$ of row $\left(10.4\right.$ shoots $\left./ \mathrm{m}^{2}\right)$ is close to the present British Columbia recommendation based on local research (Reynolds, $1988,1989)$, while 36 shoots $/ \mathrm{m}$ of row $\left(14.9 \mathrm{shoots} / \mathrm{m}^{2}\right)$ is within the expected range for mechanized pruning. 


\section{SHOOT DENSITY X CROP LEVEL AGED 1989}

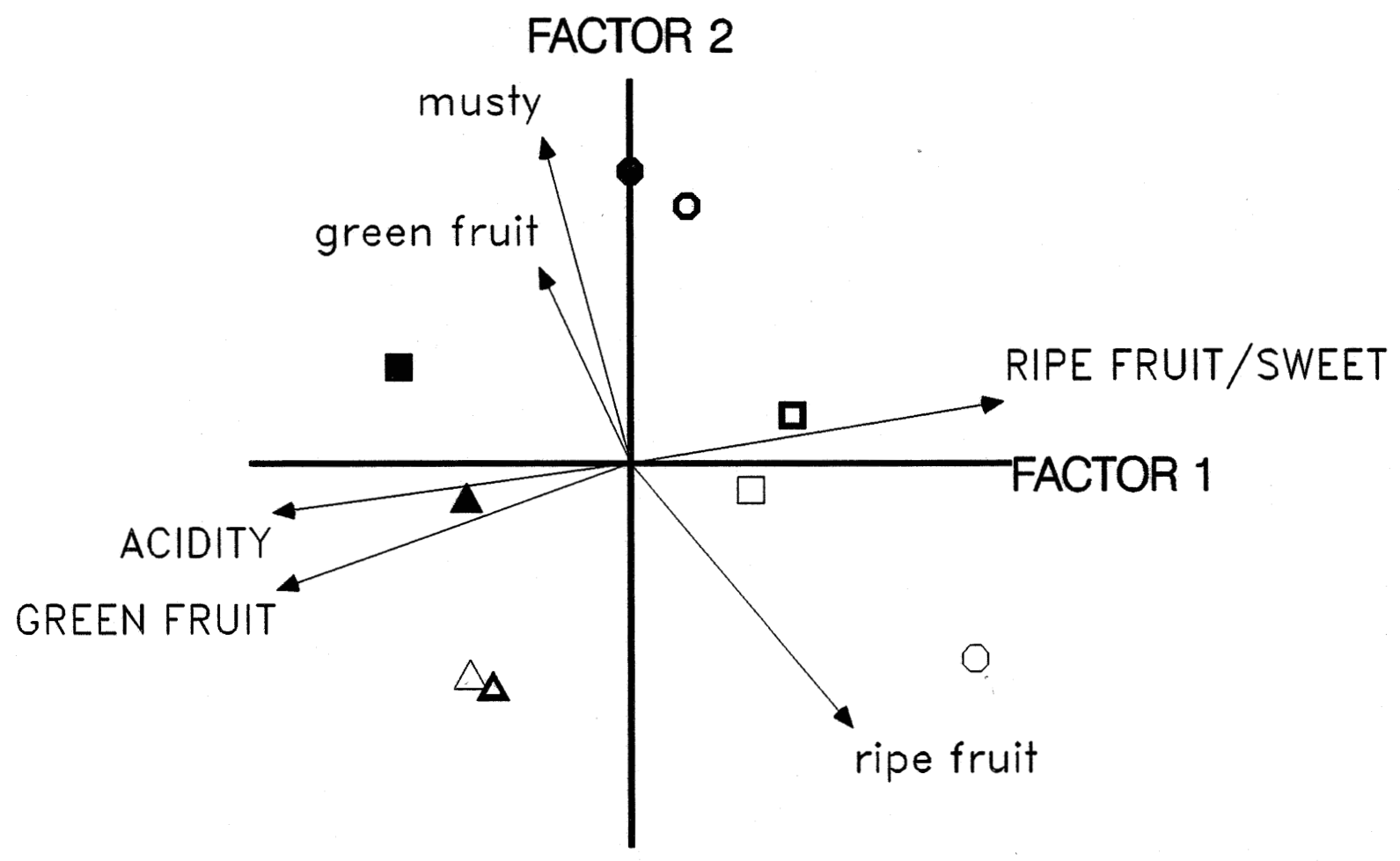

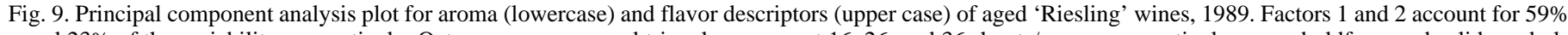

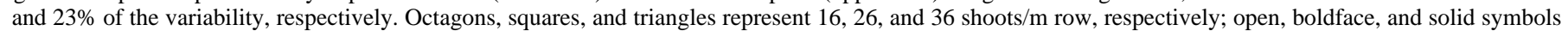
represent $1,1.5$, and 2 clusters/shoot, respectively.

Impact of shoot density and crop-thinning level on wine aroma compounds was consistent with the response of other measurements of fruit, juice, and wine composition. In most cases, hexenols increased with increasing shoot density and crop-thinning level, while monoterpenes decreased. Shoot density effects were clearest when comparisons were made between treatment combinations containing similar cluster numbers but differing shoot densities. These results are consistent with those of Smith et al. (1988), who observed higher levels of monoterpenes in 'Sauvignon blanc' juices obtained from leaf-plucked vines compared to non-leafplucked vines. The large magnitude of increase during bottle storage in wine terpenes in the 26 and 36 shoots/m treatments may have been a consequence of the trend toward increased berry and juice free volatile terpenes with increasing shoot density.

The trends in fruit composition observed in response to shoot density and crop-thinning level were clearly evident in the sensory analysis. Ranges in soluble solids, TA, $\mathrm{pH}$, and monoterpenes in the juices used in winemaking were quite small, and maximum and minimum values did not correspond to treatment combinations with highest and lowest yields. Major differences between treatment combinations were nonetheless observed in the wine descriptors. Shoot density seemed to have the greatest impact on the degree of ripe- and green-fruit flavor in the wines. Relatively small differences existed between the 16 shoots/m combinations and the $26 / 1$ and 26/1.5 treatments in terms of ripe and green-fruit flavors, but all 36 shoots/m combinations were dramatically different from the rest. This suggests that the large increases in canopy density observed between 26 and 36 shoots/m may have a major impact on wine quality, despite negligible differences in juice composition. It also provides evidence that substantial crop load ranges (6.4 to 19.7 for the 16/1 and 26/1.5 combinations, respectively) may be tolerated without large measurable differences in fruit composition or wine quality.

The impact of wine aging on aroma compounds and, ultimately, sensory response has received some attention. Simpson and Miller (1983) found small increases in trans-3-hex-1-ol, cis-hexanol, and cis-furan-linalool oxide in 'Riesling' wines as they aged, but these increases may have simply been effects of season. Similarly, Rapp and Mandery (1986) reported on changes in aroma volatiles of 'Riesling' wines made between 1964 and 1982. In general, free terpene alcohols such as linalool and geraniol decreased, while linalool oxides, nerol oxides, and hotrienol increased. The major group of constituents associated with aging of 'Riesling' wines has been the carotenoid degradation products $\left(\mathrm{C}_{13}\right.$ norisoprenoids $)$ such as damascenone and 1,1,6-trimethyl-1,2-dihydronaphthalene (Marais et al., 1992; Rapp and Mandery, 1986; Simpson and Miller, 1983). Marais et al. (1992) also correlated an increase in kerosene character and a decrease in young wine character with the changes in monoterpenes and norisoprenoids during aging of 'Riesling' wines. This is the first study of which we are aware that 
Table 3. Correlation matrix of taster scores and concentrations of aroma compounds in 'Riesling' wines pooled across nine vineyard treatments in 1989.

\begin{tabular}{|c|c|c|c|c|c|c|c|c|c|c|c|c|c|}
\hline & $\begin{array}{c}\text { Green } \\
\text { fruit } \\
\text { aroma }\end{array}$ & $\begin{array}{l}\text { Musty } \\
\text { aroma }\end{array}$ & $\begin{array}{l}\text { Ripe } \\
\text { fruit } \\
\text { flavor }\end{array}$ & $\begin{array}{c}\text { Green } \\
\text { fruit } \\
\text { flavor }\end{array}$ & Sweetness & Acidity & $\begin{array}{c}\text { Trans- } \\
\text { hexenol }\end{array}$ & $\begin{array}{c}\text { Cis- } \\
\text { hexenol }\end{array}$ & Linalool & Citronellol $\alpha$ & t-Terpineol & $\begin{array}{c}\text { Linalool } \\
\text { oxide } 1\end{array}$ & $\begin{array}{r}\text { Linalool } \\
\text { oxide } 2\end{array}$ \\
\hline Ripe fruit aroma & $\begin{array}{c}-0.14 \\
*\end{array}$ & $\begin{array}{c}-0.24 \\
* * *\end{array}$ & $\begin{array}{l}0.38 \\
* * * *\end{array}$ & 0.00 & $\begin{array}{c}0.18 \\
* *\end{array}$ & 0.04 & 0.07 & -0.03 & 0.05 & 0.02 & -0.06 & -0.06 & 0.04 \\
\hline Green fruit aroma & & $\begin{array}{l}0.31 \\
* * * *\end{array}$ & 0.10 & $\begin{array}{c}0.18 \\
* *\end{array}$ & $\begin{array}{c}0.20 \\
* *\end{array}$ & 0.10 & -0.10 & 0.00 & 0.00 & -0.04 & 0.08 & 0.05 & -0.01 \\
\hline Musty aroma & & & 0.10 & 0.09 & $\begin{array}{c}0.15 \\
*\end{array}$ & 0.09 & -0.06 & -0.02 & 0.03 & 0.03 & 0.11 & 0.09 & 0.01 \\
\hline Ripe flavor & & & & $\begin{array}{l}-0.31 \\
* * *\end{array}$ & $\begin{array}{l}0.63 \\
* * *\end{array}$ & -0.12 & 0.05 & $\begin{array}{c}-0.20 \\
* *\end{array}$ & $\begin{array}{c}0.19 \\
* *\end{array}$ & -0.13 & 0.03 & $\begin{array}{c}-0.17 \\
* *\end{array}$ & 0.02 \\
\hline Green flavor & & & & & $\begin{array}{c}-0.18 \\
* *\end{array}$ & $\begin{array}{l}0.49 \\
* * *\end{array}$ & -0.08 & $\begin{array}{l}0.22 \\
* * *\end{array}$ & $\begin{array}{c}-0.25 \\
* * *\end{array}$ & 0.09 & -0.06 & $\begin{array}{c}-0.18 \\
* *\end{array}$ & $\begin{array}{c}-0.15 \\
*\end{array}$ \\
\hline Sweetness & & & & & & $\begin{array}{c}-0.14 \\
*\end{array}$ & 0.01 & $\begin{array}{c}-0.21 \\
* * *\end{array}$ & $\begin{array}{c}0.15 \\
*\end{array}$ & $\begin{array}{c}-0.14 \\
*\end{array}$ & 0.03 & $\begin{array}{c}-0.15 \\
*\end{array}$ & 0.05 \\
\hline Acidity & & & & & & & 0.01 & $\begin{array}{l}0.23 \\
* * *\end{array}$ & -0.12 & -0.04 & -0.02 & $\begin{array}{c}0.18 \\
* *\end{array}$ & 0.02 \\
\hline Trans-hexenol & & & & & & & & $\begin{array}{l}0.58 \\
* * *\end{array}$ & $\begin{array}{l}0.35 \\
* * *\end{array}$ & -0.02 & 0.06 & $\begin{array}{l}0.30 \\
* * *\end{array}$ & $\begin{array}{l}0.44 \\
* * *\end{array}$ \\
\hline Cis-hexenol & & & & & & & & & -0.08 & $\begin{array}{l}-0.27 \\
* * *\end{array}$ & $\begin{array}{c}0.17 \\
* *\end{array}$ & $\begin{array}{l}0.68 \\
* * *\end{array}$ & $\begin{array}{l}0.32 \\
* * *\end{array}$ \\
\hline Linalool & & & & & & & & & & $\begin{array}{c}0.15 \\
*\end{array}$ & $\begin{array}{l}0.45 \\
* * *\end{array}$ & 0.06 & $\begin{array}{l}0.42 \\
* * *\end{array}$ \\
\hline Citronellol & & & & & & & & & & & $\begin{array}{l}0.34 \\
* * *\end{array}$ & 0.07 & -0.04 \\
\hline$\alpha$-Terpineol & & & & & & & & & & & & $\begin{array}{l}0.59 \\
* * *\end{array}$ & $\begin{array}{l}0.43 \\
* * *\end{array}$ \\
\hline Linalool oxide 1 & & & & & & & & & & & & & $\begin{array}{l}0.52 \\
* * *\end{array}$ \\
\hline
\end{tabular}

Significant at $P \leq 0.05,0.01$, or 0.001 , respectively.

examines effects of viticultural practices on the changes in aroma compounds during wine aging.

Taster response was most closely related to levels of aroma compounds in the aged wines, specifically the hexenols (responsible for the green-fruit flavor) and linalool (responsible for the ripe-fruit flavor). The hexenols also were related to the tasters' perception of acidity in the wines, while linalool may have increased the tasters' perception of sweetness.

Our recommendations of 20 to 25 shoots/m of row for 'Riesling' and similar medium-clustered $V$. vinifera ('Chardonnay', 'Pinot blanc', etc.) seem reasonable based on data presented here. Significant light attenuation in the canopies, coupled with reduced wine quality, takes place somewhere at $\approx 20$ to 30 shoots $/ \mathrm{m}$ of row. Substantial increases in crop load seem to have little impact on wine sensory quality unless accompanied by major increases in canopy shading.

\section{Literature Cited}

Amerine, M.A. and C.S. Ough. 1980. Methods of analysis of musts and wines. Wiley, New York.

Basler, P. 1980. Zur optimalen Belastung der Reben beim Riesling X Sylvaner am Zurichsee. Schweiz. Z. Obst-und Weinbau 116(3):56-64.

Basler, P. 1981. Zur optimalen Belastung der Reben beim Blauburgunder in der Ostschweiz. Schweiz. Z. Obst-und Weinbau 117(13):354-364.

DiStefano, R. and M. Castino. 1983. Evoluzione dei composti di natura terpenica durante la conservazione dell'Asti Spumante. Riv. Viticult. Enol. Conegliano 36:245-258.

Eschenbruch, R., R.E. Smart, B.M. Fisher, and J.G. Whittles. 1987. Influence of yield manipulations on the terpene content of juices and wines of Müller-Thurgau, p. 89-93. In: T. Lee (ed.). Proc. 6th Austral. Wine Ind. Tech. Conf. Australian Industrial Publishers, Adelaide.

Fisher, K.H., O.A. Bradt, J. Wiebe, and V.A. Dirks. 1977. Cluster thinning 'De Chaunac' French hybrid grapes improves vine vigor and fruit quality in Ontario. J. Amer. Soc. Hort. Sci. 102:162-165.
Kiefer, W. and P. Crusius. 1984. Beziehungungen zwischen Anschnitt, Mengenertrag und Qualität bei verschiedenen Rebsorten. Mitt. Klosterneuburg 34:51-63.

Marais, J., C.J. van Wyck, and A. Rapp. 1992. Effect of storage time, temperature, and region on the levels of 1,1,6-trimethyl-1,2dihydronaphthalene and other volatiles, and on quality of Weisser Riesling wines. S. African J. Enol. Viticult. 13:33-44.

McCarthy, M.G. 1986. Influence of irrigation, crop thinning, and canopy manipulation on composition and aroma of Riesling grapes. MS thesis. Waite Agr. Inst., Glen Osmond, Australia.

Morris, J.R., C.A. Sims, J.E. Bourque, and J.L. Oakes. 1984. Influence of training system, pruning severity, and spur length on yield and quality of six French-American hybrid grape cultivars. Amer. J. Enol. Viticult. $35: 23-27$.

Murisier, F. and R. Ziegler. 1991. Effets de la charge en bourgeons et de la densité de plantation sur la potentiel de production, sur la qualité du raisin et sur de développement végétatif. Essais sur Chasselas. Revue Suisse Viticult. Arboricult. Hort. 23:277-282.

Nicolosi-Asmundo, C., M.C. Cataldi Lupo, S. Campisi, and C. Russo. 1988. I componenti volatili dell' aroma del Moscato di Noto in relazione all'invecchiamento. Vignevini (10):63-67.

Nikov, M. 1987. Influence de la charge sur la production et la croissance de la vigne (c.v. Merlot). Connaissance Vigne Vin 21:81-91.

Partridge, N.L. 1925. Growth and yield of Concord grape vines. Proc. Amer. Soc. Hort. Sci. 22:84-87.

Rapp, A. 1990. Wine aroma substances from gas chromatographic analysis, p. 29-66. In: H.F. Linskens and J.F. Jackson (eds.). Wine analysis. Springer-Verlag, Berlin.

Rapp, A. and H. Mandery. 1986. Wine aroma. Experientia 42:873-884.

Reynolds, A.G. 1988. Response of Riesling vines to training system and pruning strategy. Vitis 27:229-242.

Reynolds, A.G. 1989. 'Riesling' grapes respond to cluster thinning and shoot density manipulation. J. Amer. Soc. Hort. Sci. 114:364-368.

Reynolds, A.G., C.G. Edwards, D.A. Wardle, D.R. Webster, and M. Dever. 1994. Shoot density affects 'Riesling' grapevines. I. Vine performance. J. Amer. Soc. Hort. Sci. 119:874-880. 
Reynolds, A.G., R.M. Pool, and L.R. Mattick. 1986. Effect of shoot density and crop control on growth, yield, fruit composition, and wine quality of 'Seyval blanc'. J. Amer. Soc. Hort. Sci. 111:55-63.

Reynolds, A.G. and D.A. Wardle. 1989a. Impact of several canopy manipulation practices on growth, yield, fruit composition, and wine quality of Gewürztraminer. Amer. J. Enol. Viticult. 40:121-129.

Reynolds, A.G. and D.A. Wardle. 1989b. Influence of fruit microclimate on monoterpene levels of Gewürztraminer. Amer. J. Enol. Viticult. 40:149-154.

Reynolds, A.G., D.A. Wardle, and J. Hogue. 1991. Impact of training system, vine spacing, and basal leaf removal on the performance of Riesling vines. Amer. Soc. Enol. Viticult., 42nd Annu. Meeting, Seattle. (Abstr.)

Shaulis, N.J. 1982. Responses of grapevines and grapes to spacing of and within canopies, p. 353-361. In: A.D. Webb (ed.). Proc. Centennial Symp. Grapes and Wines, Univ. of California, Davis. Univ. of California Press, Berkeley.

Shaulis, N.J. and P. May. 1971. Response of 'Sultana' vines to training on a divided canopy and to shoot crowding. Amer. J. Enol. Viticult. 22:215-222.

Shaulis, N.J. and G.D. Oberle. 1948. Some effects of pruning severity and training on Fredonia and Concord grapes. Proc. Amer. Soc. Hort. Sci. 51:263-270.

Shaulis, N.J. and W.B. Robinson. 1953. The effect of season, pruning severity, and trellising on some chemical characteristics of Concord and Fredonia grape juice. Proc. Amer. Soc. Hort. Sci. 62:214-220.

Simpson, R.F. and G.C. Miller. 1983. Aroma composition of aged Riesling wine. Vitis 22:51-63.

Smart, R.E. 1988. Shoot spacing and canopy light microclimate. Amer. J. Enol. Viticult. 39:325-333.

Smith, S., I.C. Codrington, M. Robertson, and R.E. Smart. 1988. Viticultural and oenological implications of leaf removal for New Zealand vineyards, p. 127-133. In: R.E. Smart, R.J. Thornton, S.B. Rodigues, and J.E. Young (eds.). Proc. 2nd Intl. Symp. Cool Climate Viticult. Oenol., N.Z. Soc. Viticult. Oenol., Auckland.

Tomkins, J. and N.J. Shaulis. 1955. The Catawba grape in New York. II. Some effects of severity of pruning on the production of fruit and wood. Proc. Amer. Soc. Hort. Sci. 66:214-219.

Webster, D., C.G. Edwards, S. Spayd, J.C. Peterson, and B.J. Seymour. 1993. Influence of nitrogen fertilization on the concentrations of monoterpenes, higher alcohols and esters in aged White Riesling wines. Amer. J. Enol. Viticult. 44:275-284. 